\title{
PENGATURAN TINDAK PIDANA PEMERKOSAAN TERHADAP SESAMA JENIS KELAMIN DITINJAU DARI PASAL 292 KITAB UNDANG-UNDANG HUKUM PIDANA
}

\author{
Tia Nur Larasati, I Nyoman Gede Sugiartha, Diah Gayatri Sudibya \\ Fakultas Hukum, Universitas Warmadewa, Denpasar-Bali, Indonesia \\ tiyalarasati@yahoo.com, nyomansugiarthaj4@gmail.com, diahgayatrisudibya@gmail.com
}

\begin{abstract}
Abstrak
Pemidanaan terhadap pelaku pemerkosaan sesama jenis kelamin dapat dikatakan masih memuat kekaburan norma dan bahwa Undang-Undang Republik Indonesia nomor 1 Tahun 1946 tentang Peraruran Hukum Pidana atau KUHP tidak memuat ketentuan khusus yang jelas mengaturnya. Pasal 292 KUHP merupakan saru-sarunya pasal KUHP yang memberikan pengaturan mengenai tindak pidana pemerkosaan terhadap sesama jenis kelamin. Namun, Pasal 292 KUHP hanya diatur mengenai tindak pidana pemerkosaan terhadap sesama jenis kelamin terhadap anak-anak di bawah umur sebagaimana untuk dapat dikategorikan sebagai unsur tindak pidana pemerkosaan yang tertuang dalam Pasal 285 KUHP, suatu tindak pidana pemerkosaan haruslah dilakukan oleh laki-Iaki terhadap perempuan. Tujuan dari penelitian ini adalah untuk mengetahui tindak pidana pemerkosaan terhadap sesama jenis kelamin menurut Pasal 292 KUHP dan untuk mengetahui sanksi hukum terhadap pelaku tindak pidana pemerkosaan terhadap sesama jenis kelamin di Indonesia. Metode penelitian yang dilakukan adalah penelitian normatif, jenis penelitian normatif ini menitik beratkan pada pengumpulan dan analisa mendalam terhadap bahan-bahan hukum dan juga dicari maknanya guna menemukan pemecahan masalahnya. Sanksi hukum bagi pelaku tindak pidana pemerkosaan terhadap sesama jenis kelamin di fndonesia merujuk pada ketentuan Pasal 292 KUHP yakni dapat diancam dengan pidana penjara paling lama lima tahun, sebagaimana dengan bobot kejahatan suatu tindak pidana pemerkosaan baik yang dilakukan terhadap lawan jenis ataupun sesama jenis kelamin, hukuman pidana maksimal 5 (lima) tahun dianggap masih tidak memuat rasa keadilan, rumusan sanksi hukum pidana pemerkosaan pada Pasal 285 dan 292 KUHP dapat dianggap sudah kadaluarsa atau ketinggalan jaman.
\end{abstract}

Kata Kunci: Jenis Kelamin, Pemerkosaan, Pidana.

\begin{abstract}
It can be said that the conviction of perpetrators of same-sex rape can be said to still contain obscure norms and that the Law of the Republic of Indonesia number 1 of 1946 concerning Criminal Law Regulations or the KUHP does not contain specific provisions that clearly regulate it. Article 292 of the Criminal Code is the only article of the Criminal Code that provides regulations regarding the crime of same sex rape. However, Article 292 of the Criminal Code only regulates the criminal act of same sex rape against minors as it can be categorized as an element of the crime of rape as stipulated in Article 285 of the Criminal Code, a criminal act of rape must be committed by men against women. The purpose of this study was to determine the criminal act of same sex rape according to Article 292 of the Criminal Code and to determine the legal sanctions against the perpetrator of the crime of same sex rape in Indonesia. The research method used is normative research, this type of normative research focuses on the collection and in-depth analysis of legal materials and also searches for their meaning in order to find solutions to the problem. Legal sanctions for perpetrators of the crime of rape of the same sex in Indonesia refer to the provisions of Article 292 of the Criminal Code, which is punishable by a maximum imprisonment of five years, as with the weight of the crime of a criminal act of rape whether committed against the opposite sex or of the same sex, punishment a maximum sentence of 5 (five) years is deemed not to contain a sense of justice, the formulation of criminal sanctions for rape in Articles 285 and 292 of the Criminal Code can be considered to be out of date or outdated.
\end{abstract}

Keywords: Gender, Rape, Criminal. 


\section{PENDAHULUAN}

Penataan hukum positif di Indonesia mengenai pemidanaan terhadap pelaku dari tindak pidana pemerkosaan terhadap sesama jenis kelamin dapat dikatakan rnasih memuat kekaburan norma. Oalam ranah aruran hukum pidana di Indonesia yang temuat dalam UU RI No.1 Tahun 1946 tentang Peraturan Hukum Pidana atau Kitab Undang-Undang Hukum Pidana (selanjutnya disebut KUHP), tidak bisa ditemukan ketentuan khusus yang jelas mengatur mengenai pernidanaan bagi tindak pidana pemerkosaan terhadap sesama jenis kelamin, namun berkaitan dengan adanya unsur tindakan sesama jenis kelamin tersebut telah diatur dalam satu pasal khusus yakni Pasal 292 KUHP dernikian juga sebagai satu-satunya aturan dalam memberikan sanksi bagi pelaku tindak pidana pemerkosaan terhadap sesama jenis kelamin di Indonesia.

Terkait dengan pengaruran terhadap pemidanaan perbuatan asusila yang berupa tindak pidana pemerkosaan terhadap sesama jenis kelamin yang terjadi di Indonesia, instrumen hukum dalam pemidanaannya masih sangat kurang dan tidak ada ketenruan pastinya (Ari Wibowo, 2015, 97).

Upaya pemidanaan perbuatan asusila tindak pidana pemerkosaan terhadap sesama jenis kelamin ini adalah bentuk konkret dari Part of Political of Law di dalam hukum pidana Indonesia yang dikhususkan pada kebijakan unruk memformulasikan hukum pidana yang tepat sehingga dapat memberi pedoman baku ketika perumusan kebijakan legislatif, kebijakan yudikatif (aplikasinya dalam kehidupan dunia nyata akan seperti apa), dan kebijakan eksekutif( pelaksanaan atas pelanggaran ini akan diberikan sanksi seperti apa) dalam ranah hukum pidana (Arief Amrullah, 2007, 21).

Penelitian ini telah dilakukan oleh peneliti sebelumnya yang serupa, menurut Riswan (2015) berpendapat bahwa perbuatan cabul yang dilakukan oleh pasangan sesama jenis kelamin perlu dijadikan sebagai tindak pidana (delik) di Indonesia dapat didasarkan pada tiga hal medasar, yakni dasar yuridis, teoritis, dan sosiologis. Yakni dasar yuridis, bisa didasarkan pada UU Nomor 11 tahun 2012 yang memberikan landasan bagi pembentukan peraturan perundang-undangan, termasuk di dalamnya pembentukan norma hukum pidana. Dan dasar teoritis, bisa didasarkan bahwa kriminalisasi perbuatan cabul terhadap perbutan cabul yang di lakukan oleh pasangan sesama jenis kelamin telah memenuhi kriteria umum kriminalisasi yang didukung oleh bentuk teori kriminalisasi; teori moral, teori feinberg, dan teori paternalism. Kriminalisasi perbuatan homoseks dan lesbian dipandang penting oleh masyarakat Indonesia untuk segera dilakukan, mengingat kondisi masyarakat bangsa indonesia yang diselimuti ketakutan akan menjadi korban perbuatan homoseks dan lesbian serta serangan penyakit HIV/AIDS secara besar-besaran. landasan justifikasi kriminalisasi perbuatan homoseks dan lesbian. Tiga landasan justifikasi dalam pembahasan urgensi kriminalisasi homoseksual dan lesbian yaitu filosofis, yuridis dan normatif (Anggraini, 2019). Perbuatan cabul LGBT tidak hanya bertentangan dengan peraturanperaturan yang ada seperti UndangUndang Perkawinan, melainkan juga bertentangan dengan norma budaya dan agama sebagian besar masyarakat Indonesia. Kriminalisasi perbuatan cabul LGBT dapat dinilai sebagai upaya negara untuk mengedepankan fungsi utama hukum pidana, yaitu untuk memelihara moralitas dan menjaga ketertiban masyarakat. Namun demikian pembentuk undangundang (DPR dan Pemerintah) tidak hanya harus membuat rumusan yang jelas tentang apa yang dimaksud dengan perbuatan cabul sesame kelamin (LGBT) namun juga harus memperhitungkan halhal terkait dengan penegakan hukumnya, seperti masalah pembuktiannya dan bagaimana penegakan hukum terhadap pelanggaran perbuatan cabul LGBT, tanpa melanggar hak privasi individu (Lidya Suryani Widayati, 2018).

Tujuan dari penelitian ini adalah untuk mengetahui tindak pidana pemerkosaan terhadap sesama jenis kelamin menurut Pasal 292 KUHP dan untuk mengetahui sanksi hukum terhadap pelaku tindak pidana pemerkosaan terhadap sesama jenis kelamin di Indonesia.

\section{METODE PENELITIAN}

Metode penelitian sebagai benruk tahapan dan cara dalam memecahkan masalah dalam penelitian ini dilakukan secara yuridis normatif. Jenis penelitian normatif ini menitik beratkan pada pengumpulan dan analisa mendalam terhadap bahan-bahan hukum dan juga dicari maknanya guna menemukan pemecahan masalahnya. Sebagian besar penggunaan bahan hukum dalam jenis penelitian norrnatif berupa kepustakaan dan kajian peraturan perundang-undangan (Sugiyono, 2012. 219). Sebagai acuan atau landasan dari dilakukannya penelitian ini, digunakan bahan hukum yang berupa aruran-aturan yang mengikat dan kemudian yang dijadikan sebagai pisau pemecahan rnasalah dalam menganalisa adalah teori-teori hukum yang telah dipaparkan sebelumnya (H. Salim HS dan Erlies Septiana Nurbani, 2014, 
11). Sebagai penelitian normatif, pembahasan nantinya akan berfokus pada penunjukan makna, kaidah, norma, maupun asas-asas hukurn (pemaknaan perbuatan cabul, pemerkosaan sesama jenis, dan LGBT) yang sekiranya memiliki relevansi dengan rumusan rnasalah (yang berkaitan dengan pengaturan pidana pemerkosaan terhadap sesama jenis kelamin secara nasional maupun intemasional). Adapun dalam pembahasan nantinya akan menunjuk beberapa jenis instrumen hukum berupa peraturan perundangundangan dan juga perjanjian- perjanjian intemasional yang berlaku juga di Indonesia (Amiruddin dan Zainal Asikin, 2012, 166 ). Dalam penelitian ini, sebagai upaya memperdalam pembahasan maka dipergunakan bentuk Statute Approach dan Conceptual Approach. Pendekatan perundang-undangan atau statute approach ini diperlukan dalam menentukan dan juga menganalisis jenis permasalahan yang dibahas melalui ketentuan perundang-undangan dalam segala bentuknya yang dalam skripsi ini terutama pada penggunaan ketenruan-ketentuan hukum yang intinya mengatur mengenai pemidanaan perbuatan cabul sesama jenis baik aturan secara nasional maupun intemasional guna membentuk suatu resolve yang relevan dan akurat. Penggunaan dari Pendekatan Konsep Hukum atau conceptual approach sebagai upaya rnernbentuk pemecahan ma alah terhadap kekaburan norma yang menjadi isu hukum dalam penelitian ini, yang khususnya dalam pembentukan formulasi hukum mengenai pengaturan tindak pidana pemerkosaan terhadap sesama jenis kelamin di Indonesia sebagaimana yang telah diuraikan dalam perumusan masalah sebelumnya.

\section{BASIL PENELITIAN DAN PEMBAHASAN}

\section{Pengaturan Tindak Pidana Pemerkosaan Terhadap Sesama Jenis Kelamin Menurut Pasal 292} KUHP.

Berkaitan dengan pengertian tindak pidana pemerkosaan, berdasarkan pada ketenruan Pasal 285 KUHP disebutkan bahwa kejahatan yang disebut pemerkosaan harus dilakukan oleh seorang pria terhadap seorang wanita. Berangkat dari gambaran Pasal 285 ayat (l) KUHP, maka dipahami bahwa perkosaan adalah tindak kekerasan, atau tindak kekerasan dengan tanda-tanda kekerasan yang memaksa perempuan bukan istri menderita. Ancaman apa yang membuat seorang wanita tidak berdaya, sehingga dia bisa berhubungan seks.

Menurut Wirjono Prodjodikoro, istilah pemerkosaan untuk maksud menerjemahkan kualifikasi asli (yaitu bahasa Belanda) tidak tepat, karena istilah pemerkosaan dalam Pasal 285 KUHP tidak secara tegas menjelaskan pemerkosaan. Mencuri kekuasaan sebenarnya adalah pemerkosaan. Seorang pria dan memaksa seorang wanita yang bukan seorang istri (Abdul Wahid dan Muhammad Irfan, 2001:41).

Terkait hal tersebut, Abdul Wahid dan Muhammad lrfan berbagi definisi baru tentang perkosaan, yaitu kekerasan terkait kaitan yang diciptakan oleh pelanggaran hukum. Memahami pemerkosaan sebagai pemikiran berarti mengeluarkan has rat seksual seseorang melalui paksaan, yang bertentangan dengan norma, termasuk kegiatan antisosial.

Undang-undang pidana Indonesia selama ini hanya mengatur aturan yang melarang perkosaan heteroseksual, yang rnenetapkan bahwa baik pelaku laki-laki maupun perempuan korban tunduk pada hukum pidana Pasal 285 KUHP. Namun ketentuan dalam KUHP tidak mengatur tentang pemerkosaan sesama jenis, yaitu usia pelaku dan korban sesama jenis sudah cukup umur.

Sebenarnya, ketidak sesuaiannya unsur delik yang dipunyai KUHP dalam pengaturan kekejaman seksual utamanya terhadap tindak pidana pemerkosaan yang dilakukan terhadap sesama jenis kelamin belum sepenuhnya memiliki aturan. Kekejaman seksual yang dimaksud dalam penelitian ini adalah kejahatan seksual dalam bentuk pemerkosaan, berupa hubungan seksual paksa atau pemerkosaan sesamajenis.

Perkosaan bisa disebut sebagai pseudoseksual Dalam kebanyakan kasus pemerkosaan, ekspresi kemarahan, keinginan untuk mendominasi dan melumpuhkan (kegagalan) lebih menonjol daripada hasrat seksual itu sendiri, yang tercermin sepenuhnya dalam agresi seksual (Tapi Ommas Ihromi, 2000, 278)

Dalam ketentuan KUHP, tidak bisa ditemukan ketentuan khusus yang jelas mengatur mengenai pemidanaan bagi tindak pidana pernerkosaan terhadap sesama jenis kelamin, namun berkaitan dengan adanya unsurtindakan sesamajenis kelamin tersebut telah diatur dalam satu pasal khusus yakni Pasal 292 KUHP demikian juga sebagai saru-sarunya aruran dalam memberikan sanksi bagi pelaku tindak pidana pemerkosaan terhadap sesama jenis kelamin di Indonesia. Adapun penjabaran terhadap ketentuan Pasal 292 KUHP tersebut adalah sebagai berikut: 
1. Ketentuan Pasal 292 KUHP yang menyebutkan bahwa ketentuan Pasal 292 KUHP telah melarang terhadap perbuatan tidak senonoh antar jenis, namun hanya yang dilakukan oleh orang yang cukup umur dengan orang di bawah umur saja.

2. Pasal 292 KUHP menyampaikan dengan eksplisit mengenai unsur sesama jenis kelamin terhadap orang yang belum cukup umur, namun terkait dengan adanya suatu perbuatan cabul, sebagaimana berkaitan dengan delik-delik perkosaan yang dikenal dalam hukum pidana di Indonesia.

3. Pasal 292 KUHP merupakan satu-satunya pasal dalam KUHP yang memberikan gambaran buram pengaturan terhadap tindak pidana yang dilakukan terhadap sesama jenis kelamin.

Berdasarkan pada ketentuan tersebut di atas, dapat diperoleh beberapa unsur dari tindak pidana pemerkosaan terhadap sesama jenis kelamin yang dapat dijabarkan sebagai berikut:

1. Melakukan Perbuatan Cabul

Menurut KBBI, kecabulan itujorok,jorok, dan tidak senonoh, bukan berarti sopan dan santun. Hukum Pidana tidak menyangkal arti istilah kecabulan, namun menurut Pasal 289 KUHP, jika kecabulan dibiarkan terus menerus atau dibiarkan dengan paksaan atau ancaman, maka akan dijatuhi pidana penjara paling lama 9 tahun. Artinya, bertentangan dengan reputasi dan etiket.

2. Sesama Jenis Kelamin

Homosexuality atau homoseksualitas artinya memiliki hasrat seksual untuk sesame jenis (Wirah Aryoso dan Hermawan SyaifuJ, 2013:231). Menurut KBBI. Homoseksualitas diartikan dari kata sesama jenis, homo artinya sama, dan gender artinya jenis kelamin.

3. Dilakukan Terhadap Orang yang Belum Dewasa

Yang dimaksud belum dewasa ialah anak-anak yang belum genap berusia 18tahun. Untuk kepastian yudisial dan hukum, peraturan perundang-undangan di Indonesia hams segera diterapkan untuk tindak pidana pemerkosaan terhadap sesama jenis. Rumusan persyaratannya harus sederhana dan mudah dipaharni, tetapi dapat dibayar. Hasil tersebut sejalan dengan tujuan hukum pidana bagi masyarakat yang sedang menjalani proses perbaikan dan modemisasi, yaitu tujuan pembuatan undang-undang baru (mengembangkan undang-undang baru), memperkuat hukum pidana yang sudah ada (memperkuat undang-undang yang sudah ada), dan memperkuat tindak pidana. Hukum. Batasan ruang lingkup hukum pidana sudah ada (untuk memperjelas ruang lingkup dan fungsi undang-undang yang ada).

2. Sanksi Hukum Terhadap Pelaku Tindak Pidana Pemerkosaan Terhadap Sesama Jenis Kelamin Di Indonesia.

Tindak pidana pemerkosaan saat ini tidak dapat hanya dilihat sebagai bentuk kejahatan yang hanya selaku kegiatan privat (individu korban), tapi harus dijadikan sebagai problem khalayak umum, karna jenis kejahatan ini macam-macam ialah bentuk kelakuan kuno yang mengedepankan ambisi, geram dan superioritas, yakni siapa yang kuat itulah yang berhak mengabdikan orang lain.

Kasus pemerkosaan bukan lagi sekedar masalah interpersonal, tetapi masalah sosial yang berkaitan dengan masalah interpersonal, tetapi masalah sosial yang berkaitan dengan masalah hak asasi manusia, terutama yang terkait dengan berbagai bentuk penyiksaan, kekerasan, dan tindakan kejam yang mengabaikan martabat orang dalam pembelaannya (Abdul Wahid dan Muhammad lrfan, 2001, 62 ).

KUHP mempunyai rumusan tindak pidana yang sangat terpaku saat menata mengenai bentuk kekejaman seksual kepada sesamajenis kelamin utamanya adalah dalam hal perkosaan yang pada Pasal 285 KUHP. Sejatinya, pengertian perkosaan yang disebutkan pasal di atas mernagari kejahatan perkosaan cuma bisa berlaku antara pria kepada perernpuan yang bukan istrinya. Jadi, tindak pidana pemerkosaan terhadap sesama jenis kelamin dikeluarkan dari pengertian perkosaan dalam Pasal 285 KUHP. Ditinjau dari pasal tersebut diketahui bahwa perkosaan antara sesarna jenis (terhadap sesama pria atau terhadap sesama perempuan) ialah dikiranya tidak merupakan tindak pidana pemerkosaan.

\section{SIMPULAN DAN SARAN}

\section{Kesimpulan}

Kesimpulan dari hasil penelitian ini adalah sebagai berikut:

1. Pasal 292 KUHP merupakan satu-sarunya pasal KUHP yang memberikan pengaturan untuk tindak pidana yang dilaksanakan terhadap jenis kelamin yang sama. Pengaturan tindak pidana pemerkosaan terhadap sesama jenis kelamin berdasarkan pada Pasal 292 KUHP hanya diatur mengenai tindak pidana pemerkosaan terhadap sesama jenis kelamin terhadap anak-anak di bawah umur sebagaimana 
untuk dapat dikategorikan sebagai unsur tindak pidana pernerkosaan yang tertuang dalam Pasal 285 KUHP, suatu kejahatan pidana pernerkosaan haruslah dilakukan oleh laki-laki kepada perempuan.

2. Sanksi hukum bagi pelaku tindak pidana pemerkosaan kepada sesama jenis kelamin di lndonesia merujuk pada ketentuan Pasal 292 KUHP yakni dapat dijerat kurungan penjara paling lama lima tahun, sebagaimana dengan bobot kejahatan suatu tindak pidana pemerkosaan baik yang dilakukan kepada lawan jenis maupun sesama jenis kelamin, hukuman pidana maksimal 5 (lima) tahun dianggap masih tidak memuat rasa keadilan, sehingga dapat disimpulkan bahwa rumusan sanksi hukum pidana pemerkosaan pada Pasa J 285 dan 292 KUHP dapat dianggap sudah kadaJuarsa atau ketinggalan jaman.

\section{Saran}

Berikut adalah beberapa saran yang penulis berikan untuk arah perkembangan selanjutnya:

1. Hendaknya pemerintah dan para pembuat peraturan perundang-undangan mampu rnerumuskan ulang delik-delik perkosaan yang tercantum dalam KUHP, demi keadilan bagi para korban pemerkosaan dan memberikan jarninan kejelasan hukum daJam penggarapan kasus-kasus pemerkosaan yang terjadi di wilayah hukum Indonesia, sehingga sudah sepatutnya delik pemerkosaan dalam KUHP memang harus dirumuskan ulang.

2. Hendaknya seluruh masyarakat dapat menyadari bahwa bahaya dari pelaku tindak pidana pemerkosaan saat ini tidak hanya menimpa kaum perempuan sebagaimana diperlukan upaya lebih dalam mengatasi yang dapat rnelibatkan pihak keluarga, masyarakat, dan negara.

\section{DAFTAR PUSTAKA}

Anggraini, S. A. (2019). Gagasan Kebijakan Hukum Pidana Terhadap Kriminalisasi Hubungan

Seksual Sejenis di Indonesia. Jurnal Online Mahasiswa Fakultas Hukum, Vol 6(2).

Amiruddin, \& Asikin, Z. (2012). Pengantar Metode Penelitian Hukum (Cet.4). Raja Grafindo

Persada. Jakarta.

Amrullah, A. (2007). Politik Hukum Pidana Dalam Perlindungan Korban Kejahatan. Bayumedia Publishing. Malang.

Aryoso, Wirah, \& Syaiful, H. (2013). Kamus Pintar Bahasa Indonesia. Pustaka Makmur, Jakarta.

Erfa, R. (2015). Kriminalisasi Perbuatan Cabul Yang Dilakukan Oleh Pasangan Sesama Jenis

Kelamin (Homoseksual). Arena Hukum, Vol 8(2), 236-257.

HS, S. H., \& Nurbani, E. S. (2014). Penerapan Teori Hukum pada Penelitian Tesis dan Disertasi.

Rajawali Pers. Jakarta.

Ihromi, T. O. (2000). Penghapusan Diskriminasi Terhadap Kaum Wanita. Alumni Bandung.

Sugiyono. (2012). Metode Penelitian Kuantitatif Kualitatif dan R\&D. Alfabeta. Bandung.

Wahid, A., \& Lrfan, M. (2001). Perlindungan Terhadap Korban Kekerasan Seksual. Refika Aditima, Bandung.

Wibowo, A. (2015). Tinjauan Teoritis Terhadap Wacana Mengenai Kriminalisasi LGBT. Cakrawala Hukum, Vol. 11(1).

Widayati, L. S. (2018). Kriminalisasi Perbuatan Cabul Lesbian, Gay, Biseksual, Dan Transgender (Lgbt). Info Singkat Kajian Singkat Terhadap Isu Aktual Dan Strategis, Vol 10(3). 